\title{
HYPERACCUMULATION OF NI BY ALYSSUM MURALE WALDST. \& KIT. FROM ULTRAMAFICS IN BOSNIA AND HERZEGOVINA
}

\author{
MatKo StAmenKović, U..$^{*}$ - ANDREJIĆ, G. ${ }^{1,2}$ - Mihailović, N. ${ }^{2}$ - ŠINŽAR-SeKUlić, J. ${ }^{1}$ \\ ${ }^{I}$ Institute of Botany and Botanical Garden, Faculty of Biology, University of Belgrade, \\ Takovska 43, 11000 Belgrade, Serbia \\ ${ }^{2}$ Institute for the Application of Nuclear Energy, \\ Banatska 31b, 11080 Belgrade, Serbia \\ *Corresponding author \\ e-mail:munamu@gmail.com
}

(Received $2^{\text {nd }}$ Nov 2016; accepted $11^{\text {th }}$ Mar 2017)

\begin{abstract}
We investigate the nickel concentration in serpentine soil samples from several areas in central region of Bosnia and Herzegovina. Concentration of some other elements such as $\mathrm{P}, \mathrm{K}, \mathrm{Ca}, \mathrm{Mg}, \mathrm{Fe}, \mathrm{Mn}$, $\mathrm{Pb}, \mathrm{Co}$, and $\mathrm{Cd}$ were determined as well. Selected soil samples were typical of ultramafic sites with low concentrations of $\mathrm{P}, \mathrm{K}$ and $\mathrm{Ca}$ and high concentrations of $\mathrm{Mg}, \mathrm{Fe}, \mathrm{Ni}$ and $\mathrm{Zn}$. The $\mathrm{Mg} / \mathrm{Ca}$ ratio was relatively high (0.78-30.61). The levels of $\mathrm{P}, \mathrm{K}, \mathrm{Fe}$ and $\mathrm{Zn}$ were high, $\mathrm{Mn}$ and $\mathrm{Cu}$ occurred in low amounts, whereas, $\mathrm{Cd}, \mathrm{Co}$ and $\mathrm{Pb}$ were only traceable. Principal component analysis pointed out the correlation of elements originating from ultramafic bedrock and their possible phytoextraction. The concentration of $\mathrm{Ni}$ in tissues of all investigated plant samples was high to extremely high. High concentrations of $\mathrm{Co}$ in plant tissues were recorded also. Bearing in mind that A. murale at investigated sites in Bosnia and Herzegovina showed a high capacity for accumulation and translocation of $\mathrm{Ni}$ and generally, shared high tolerance to other metals, this plant may be used to clean up soils contaminated with heavy metals, as well as for phytomining.
\end{abstract}

Keywords: serpentine soil, nickel, soil contamination, heavy metal cleanup, phytomining, phytoextraction

\section{Introduction}

Ultramafics are defined as group of magmatic or metamorphic rocks that consist of less than $45 \%$ silica $\left(\mathrm{SiO}_{2}\right)$ and have high concentrations of magnesium $(\mathrm{Mg})$, iron $(\mathrm{Fe})$, chrome $(\mathrm{Cr})$, cobalt $(\mathrm{Co})$ and nickel $(\mathrm{Ni})$. In addition to high concentrations of those elements, ultramafic soils, developed by weathering of ultramafic bedrock, are generally characterized with low concentrations of phosphorus $(\mathrm{P})$, potassium $(\mathrm{K})$, and calcium (Ca) (Alexander et al., 2007). During the serpentine creation, the main process is metamorphism (also known as metasomatism) of primary magnesium-iron silicate minerals (Alexander et al., 2007). In the course of this process primary silicate minerals are replaced by magnesium silicate serpentine minerals (Alexander et al., 2007). Ultramafics exist world-wide, and in Europe they are concentrated on the area of Balkan Peninsula (Stevanović et al., 2003). Weathering of serpentinite and serpentine rocks differ from site to site as a result of different climatic conditions in addition to the nature of parent material and other factors such as topography, biota and time (Oze et al., 2004).

Serpentines are very special plant-soil-rocks system which are characterized with the growth of specific and extraordinary plant species, and support vegetation in remarkable physiognomic contrast with that on other soil areas (Whittaker, 1954; Lazarus et al., 
2011). Some of these characteristics are related to the fact that ultramafic soil is largely sterile and unproductive, and if the plants flourish in such harsh environment, they are generally endemic species. The infertility of these soils is characterized as serpentine unproductiveness (Karataglis et al., 1982; Jackson, 2005). A large number of plants that flourish on serpentine soil belongs to the species that are referred to as "hyperaccumulators" (Van der Ent et al., 2013). These plants can take up metal and metalloid trace elements and store them in their leaves, flowers and stems in remarkably high concentrations, thus providing an adaptation for growth on soils that otherwise might be toxic. More than 500 species of "hyperaccumulator" have been indentified, including a significant number of representatives of the family Brassicaceae (Pollard et al., 2014).

According to Broadhurst and Chaney (2016), within the family Brassicaceae, the genus Alyssum contains the largest number of ascertained Ni hyperaccumulators -50 taxa, including the species Alyssum murale Waldst. \& Kit. which is distributed in southeastern Europe, Russia, Asia Minor and southwesterm Asia (Ball and Dudley, 1993). In relation to the recent molecular, genetic and morphological evidence, from native populations, several species previously regarded as endemic hyperaccumulators can hardly be accepted as separate from $A$. murale, and we should treated all these taxa as synonyms of the species A. murale (Reeves et al., 2001; Hartvig, 2002; Whiting et al., 2003). A. murale is widespread in the serpentines in the Balkans and its accumulation potential is well documented in Serbia (Tumi et al., 2012) and, in particular, in Albania, Greece and Bulgaria (Bani et al., 2007; 2009; 2010; 2013). Morover, A. murale is reported to have a remarkable potential for application in remediation of metals in the environment, as well as a for nickel-phytomining (Li et al., 2003; Bani et al., 2015; Nkrumah et al., 2016).

Given the importance of $A$. murale as a potental source for a phytomining and the fact that there are no data on hyperaccumulation characteristic of its native populations in Bosnia and Herzegovina, nor on the soil characteristics over a wide serpentinite area in this region, the aims of this study were: (a) to investigate soil chemical properties from several serpentine sites in central region of Bosnia and Herzegovina on which this species was recorded; (b) to investigate levels of accumulation and translocation of trace metals in plant tissues (roots, stems, and leaves), with a specific focus on $\mathrm{Ni}$; and, (c) to estimate the potential use of local population for phytoextraction.

\section{Materials and Methods}

\section{Studied area}

Studied area covered dispersed serpentine outcrops in central part of Bosnia and Herzegovina, covering the surface of cca. $200 \mathrm{~km}^{2}$. Samples were taken from 10 different locations, i.e. sampling points (SP1-SP10) based of presence of large populations of $A$. murale at each site (Table 1, Fig. 1). These locations were mainly in the uninhabited locations. The low amount of topsoil is mainly derived from weathered serpentinite. The serpentine soil on all sites are rocky and very shallow, vulnerable to erosion They are characterised mainly of sparse vegetation in the vicinity of pine and oak forests. 


\section{Sample collection}

A. murale and soil samples were collected from May 2013 to May 2014 from 10 sampling points (SP), SP1-SP10 (Table 1, Fig. 1). Soil samples (cca. 500 g per sample) were taken from the main rooting area on each site, under all field-collected specimens of A. murale. Soil samples were first air-dried at room temperature, and thereafter pulverized, sieved through the $50 \mu \mathrm{m}$ sieve and oven-dried overnight.

Plant samples (cca. $500 \mathrm{~g}$ per sample) were collected from each of the investigated location, separated into roots, stems and leaves and prepared for the analysis according to the procedure described by Markert (1995). Voucher specimens of all the plants material collected are deposited in the Collections of the Institute of Botany and Botanical Garden, Faculty of Biology, University of Belgrade (BEOU).

Table 1. Locations of the sampling points of Alyssum murale populacions from Bosnia and Herzegovina

\begin{tabular}{cccc}
\hline Location & Sample point & Latitude (N) & Longitude (E) \\
\hline Bakotic & SP 1 & $44^{\circ} 32^{\prime} 22.3^{\prime \prime}$ & $18^{\circ} 10^{\prime} 27.9^{\prime \prime}$ \\
BosanskoPetrovo & SP 2 & $44^{\circ} 37^{\prime} 47.0^{\prime \prime}$ & $18^{\circ} 20^{\prime} 31.2^{\prime \prime}$ \\
Causevica & SP 3 & $44^{\circ} 29^{\prime} 19.8^{\prime \prime}$ & $18^{\circ} 10^{\prime} 57.8^{\prime \prime}$ \\
Klokotnica & SP 4 & $44^{\circ} 43^{\prime} 17.8^{\prime \prime}$ & $18^{\circ} 09^{\prime} 51.7^{\prime \prime}$ \\
Liplje & SP5 & $44^{\circ} 38^{\prime} 11.9^{\prime \prime}$ & $17^{\circ} 31^{\prime} 52.5^{\prime \prime}$ \\
Maglaj & SP 6 & $44^{\circ} 32^{\prime} 21.6^{\prime \prime}$ & $18^{\circ} 05^{\prime} 19.6^{\prime \prime}$ \\
Stanari & SP 7 & $44^{\circ} 42^{\prime} 19.3^{\prime \prime}$ & $17^{\circ} 46^{\prime} 47.7^{\prime \prime}$ \\
Sehar & SP 8 & $44^{\circ} 26^{\prime} 25.8^{\prime \prime}$ & $18^{\circ} 06^{\prime} 51.9^{\prime \prime}$ \\
Teslić & SP 9 & $44^{\circ} 36^{\prime} 58.1^{\prime \prime}$ & $17^{\circ} 49^{\prime} 29.1^{\prime \prime}$ \\
Zvornik & SP 10 & $44^{\circ} 24^{\prime} 00.1^{\prime \prime}$ & $19^{\circ} 066^{\prime} 38.1^{\prime \prime}$ \\
\hline
\end{tabular}

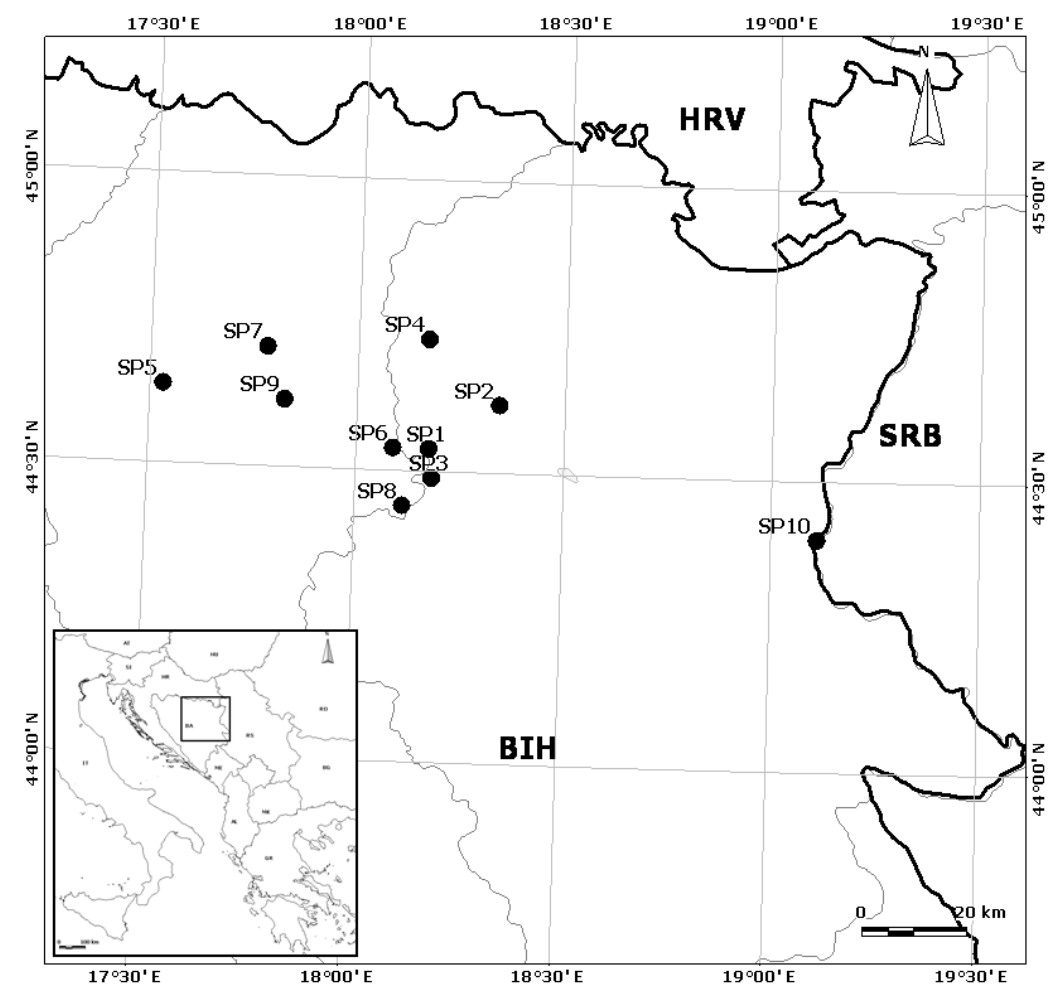

Figure 1. Map of the areas in Bosnia and Herzegovina where soil and plant samples were collected 


\section{Soil analysis}

The distribution of the particle sizes was determined after soil dispersion by sodium hexametaphosphate, using the pipette method for the silt and clay fractions and drysieving for the sand fraction (Van Reeuwijk, 1995). The sand particles are separated from clay and silt with a $50 \mu \mathrm{m}$ filter. Determination of soil textural classes was done following the USDA classification (Rowell, 1997). $\mathrm{pH}$ of soil samples (actual and exchangeable) was determined in distilled water and in $1 \mathrm{M} \mathrm{KCl}$ solution, respectively, in a solid-liquid (S/L) ratio of 1:2.5 ml/g (McKeague, 1978). Concentration of available $\mathrm{P}_{2} \mathrm{O}_{5}$ and $\mathrm{K}_{2} \mathrm{O}$ were measured in $\mathrm{AL}$ solution $(0.1 \mathrm{M}$ ammonium lactate and $0.4 \mathrm{M}$ acetic acid) extract (S/L 1:20) (Egner et al., 1960). Content of phosphate was determined by molybdenum blue method and potassium concentration was determined using FES (flame emission spectrophotometry) by Pye Unicam SP 192 atomic absorption spectrophotometer. Concentration of available $\mathrm{Ca}$ and $\mathrm{Mg}$ were determined in $1 \mathrm{M}$ ammonium acetate extract (S/L 1:50) using AAS (atomic absorption spectrophotometry) (Pye Unicam SP 192) (Van Reeuwijk, 2002). Dichromate digestion based on FAO procedure was used for determination of organic matter concentration (FAO, 1974). Concentartion of available (potentially leachable) metals in soil samples was determined by $0.1 \mathrm{~N} \mathrm{HCl}(\mathrm{S} / \mathrm{L} 1: 10)$ according to the procedure recommended by Garcia et al. (1979). Total metal extraction was done by $\mathrm{HCl}$ and $\mathrm{HNO}_{3}$ digestion (ISO 11466 1995). Metal concentrations in investigation extracts were determined using atomic absorption spectrophotometry (ISO 11047 1998) (Pye Unicam SP 192). Each analysis of the soil material was performed in triplicates as well as each chemical analysis.

\section{Plant analysis}

Dried and powdered plant material from $A$. murale was digested by slightly modified wet procedure described by ISO 6636/2, 1981, using a boiling mixture of nitric and sulphuric acids. Concentration of $\mathrm{Ca}$ in plant tissue samples was determined using FES (flame emission spectrophotometry) using a Pye Unicam SP 192 atomic absorption spectrophotometer. Metal concentrations were determined using atomic absorption spectrophotometry (Pye Unicam SP 192). The series of standard solutions for metals were made from $1 \mathrm{~g} / \mathrm{l}$ solutions purchased from Carlo Erba, Italy. Each analysis of the plant samples was performed in triplicates. In addition, each of the chemical analyses was also run with three replicates.

\section{Data analysis}

The results of soil and plant analyses are expressed as mean \pm standard deviation (SD). Normality was checked for all measured variables (Shapiro-Wilks test, $\alpha=0.05$ ), whereupon they were log transformed prior to further analysis. A principal components analysis (PCA) based on correlation matrix was done in order to reveal the relationship between analysed serpentine sites concerning the element concentrations. Measured variables used in PCA were mean-centred and standardized. The number of principal components (PCs) that were extracted from the variables was defined by Kaiser's criterion, ie. only PCs with eigenvalues higher than 1 were retained (Kaiser and Rice, 1974). Values of element concentrations in plant tissues, as well as between concentration of available elements in the soil samples and those in plants were 
compared by Pearson's correlation test using the program SPSS 19 for Windows. Differences at $\mathrm{p}<0.05$ were accepted as the level of significance.

For the evaluation of trace metal tolerance of $A$. murale, two indices were determined, bioconcentration factor (BCF) and translocation factor (TF) (Ghosh and Singh, 2005). Bioconcentration factor which indicates the overall ability of plant to accumulate trace metals was calculated as the quoient of their concentrations in shoots and the available (potentially leachable) concentrations in the soil. The translocation factor, indiacting the plant ability to translocate trace metals from the root to to the aerial parts, was calculated as the ratio of their concentrations in shoots and roots.

\section{Results}

\section{Soil characteristics}

The analysed chemical properties of 10 investigated soil samples, such as $\mathrm{pH}$, organic matter, $\mathrm{P}_{2} \mathrm{O}_{5}, \mathrm{~K}_{2} \mathrm{O}$, available concentrations of major elements $(\mathrm{Fe}, \mathrm{Ca}, \mathrm{Mg}$ ), and total and available concentrations of trace elements $(\mathrm{Ni}, \mathrm{Mn}, \mathrm{Zn}, \mathrm{Cu}, \mathrm{Cr}, \mathrm{Co}, \mathrm{Cd}$, $\mathrm{Pb}$ ), are outlined in Table 2. The $\mathrm{pH}$ of the soil samples diverse from moderately acidic to moderately alkaline, while $\mathrm{pH}$ in $1 \mathrm{M} \mathrm{KCl}$ was acidic to almost neutral. The percentage of organic matter differed within a moderate range. In regard to the concentraions of analysed elements, soil samples were more or less typical of the soil that is developed on the ultramafic rocks. Soils at the investigated sites had moderate to high concentrations of $\mathrm{Mg}$, and low to moderate concentrations of $\mathrm{Ca}$, thus having $\mathrm{Mg} / \mathrm{Ca}$ quotient $>1$ in all but one location (SP3). Futhermore, all examined soil samples had a high concentration of trace elements that are typical for serpentinite locations $(\mathrm{Ni}$, $\mathrm{Co}, \mathrm{Cr}, \mathrm{Mn}$ ), while the rest of the analysed elements were in the ranges of normal soils.

\section{Chemical composition of the plant material}

Concentrations of analysed elements in the roots, stems, and leaves of 10 analysed $A$. murale populations from sampling locations are presented in Table 3. Regarding trace metals which are typical for serpentinites, the highest concetrations of $\mathrm{Ni}$ and $\mathrm{Mn}$ were recorded in leaves, and the lowest in roots of analysed plants. The same trend was also noticed for Co, which is recorded in the extremely high concentrations (up to 142.9 $\mathrm{mg} \cdot \mathrm{kg}^{-1}$ in leaves of $A$. murale). The opposite trend was noticed for $\mathrm{Zn}$, since the concentration of $\mathrm{Zn}$ was the lowest in the leaves, while in both, in the stems and in the roots, it was significantly higher. Concentration of $\mathrm{Cd}$ was very low and similar in all investigated samples of $A$. murale. Only in several leave samples Cd concentration was slightly higher. $\mathrm{Pb}$ was not detected in plant in one location, and in all others $\mathrm{Pb}$ concentration was relatively low, especially in roots. 
Table 2. $\mathrm{pH}$, organic matter(\%), $\mathrm{P}_{2} \mathrm{O}_{5}, \mathrm{~K}_{2} \mathrm{O}$, major elements ( $\mathrm{Fe}, \mathrm{Ca}, \mathrm{Mg}$ ) and trace elements ( $\mathrm{Ni}, \mathrm{Mn}, \mathrm{Zn}, \mathrm{Cu}, \mathrm{Cr}, \mathrm{Co}, \mathrm{Cd}$, $\mathrm{Pb}$ ) concentrations (mg $\mathrm{kg}^{-1}$ ) in soils of investigated location in which Alyssum murale are present (mean $\pm S D$ )

\begin{tabular}{|c|c|c|c|c|c|c|c|c|c|c|}
\hline Sample point & SP1 & SP2 & SP3 & SP4 & SP5 & SP6 & SP7 & SP8 & SP9 & SP10 \\
\hline $\mathrm{pH}$ soil in $\mathrm{H}_{2} \mathrm{O}$ & 8.2 & 8.1 & 6.57 & 7.91 & 7.56 & 8.6 & 6.91 & 8.29 & 8.37 & 8.05 \\
\hline $\mathrm{pH}$ soil in $1 \mathrm{~N} \mathrm{KCL}$ & 7.37 & 7.33 & 5.56 & 6.92 & 6.16 & 7.49 & 6.91 & 6.96 & 7.21 & 6.9 \\
\hline Organic matter $\%$ & $0.82 \pm 0.09$ & $1.99 \pm 0.15$ & $4.85 \pm 1$ & $1.89 \pm 0.1$ & $1.98 \pm 0.1$ & $2.2 \pm 0.06$ & $1.05 \pm 0.1$ & $0.5 \pm 0.1$ & $1.24 \pm 0.07$ & $1.3 \pm 0.1$ \\
\hline $\mathrm{P}_{2} \mathrm{O}_{5}(\mathrm{a})$ & $1.72 \pm 0.2$ & $30.8 \pm 0.3$ & $3.85 \pm 0.6$ & $2.47 \pm 0.5$ & $1.37 \pm 0.2$ & $10.5 \pm 0.5$ & $5.06 \pm 0.7$ & $1.66 \pm 0.5$ & $2.87 \pm 0.4$ & $2.58 \pm 0.4$ \\
\hline $\mathrm{K}_{2} \mathrm{O}$ (a) & $9.42 \pm 0.8$ & $4.18 \pm 0.3$ & $50.3 \pm 1.9$ & $9.9 \pm 0.06$ & $9.17 \pm 0.1$ & $20.38 \pm 1.1$ & $35.42 \pm 1.3$ & $5.2 \pm 0.03$ & $13.41 \pm 0.6$ & $11.8 \pm 0.6$ \\
\hline $\mathrm{Fe}(\mathrm{a})$ & $777.7 \pm 19$ & $780.4 \pm 7.1$ & $502.1 \pm 6.6$ & $142.1 \pm 1.3$ & $678.6 \pm 11$ & $849.5 \pm 11.6$ & $387.7 \pm 3.3$ & $248.4 \pm 12.5$ & $331.5 \pm 3.6$ & $507.5 \pm 20.7$ \\
\hline $\mathrm{Ca}(\mathrm{a})$ & $1055.6 \pm 29$ & $222.9 \pm 16$ & $527.2 \pm 36$ & $317.9 \pm 8.8$ & $186.8 \pm 6.7$ & $2419.6 \pm 120$ & $414.6 \pm 16$ & $112.1 \pm 8.6$ & $687.1 \pm 51$ & $1846.6 \pm 32$ \\
\hline $\operatorname{Mg}(\mathrm{a})$ & $2422.3 \pm 56$ & $656.1 \pm 41$ & $411.2 \pm 32$ & $925.7 \pm 9.7$ & $883.1 \pm 9.8$ & $4257.6 \pm 76$ & $3631 \pm 100$ & $3429.7 \pm 330$ & $2198 \pm 135$ & $3312.2 \pm 123$ \\
\hline $\mathrm{Mg} / \mathrm{Ca}$ & 2.29 & 2.94 & 0.78 & 2.91 & 4.73 & 1.76 & 8.76 & 30.61 & 3.20 & 1.79 \\
\hline $\mathrm{Ni}(\mathrm{t})$ & $2232.1 \pm 50$ & $1675.2 \pm 38$ & $637.2 \pm 9.3$ & $2075.4 \pm 12$ & $1077.4 \pm 38$ & $2222.5 \pm 99$ & $1555.6 \pm 28$ & $1862.2 \pm 29$ & $2052.3 \pm 16$ & $2222.3 \pm 42$ \\
\hline $\mathrm{Ni}(\mathrm{a})$ & $2007.5 \pm 4.4$ & $1131.9 \pm 2.0$ & $325.4 \pm 7.5$ & $1884.7 \pm 2.9$ & $1633.9 \pm 68$ & $1456.4 \pm 24$ & $1296.9 \pm 1.4$ & $1873.1 \pm 0.7$ & $1158.3 \pm 5.1$ & $2036.2 \pm 41$ \\
\hline $\operatorname{Mn}(t)$ & $1577.6 \pm 10$ & $1772.6 \pm 102$ & $1426.1 \pm 69$ & $1735.4 \pm 54$ & $1875.7 \pm 47$ & $1458.8 \pm 15.0$ & $1298.5 \pm 6.1$ & $1884.3 \pm 105$ & $2540.1 \pm 10.7$ & $2442.7 \pm 65$ \\
\hline Mn (a) & $590.5 \pm 6.55$ & $548.8 \pm 4.5$ & $508.9 \pm 1.88$ & $426.6 \pm 15.1$ & $648.3 \pm 1.40$ & $479.8 \pm 6.39$ & $476.3 \pm 9.23$ & $150.8 \pm 9.61$ & $712.6 \pm 0.93$ & $860.0 \pm 21.6$ \\
\hline $\mathrm{Zn}(\mathrm{t})$ & $107.78 \pm 4.7$ & $36.96 \pm 3.3$ & $101.1 \pm 1.8$ & $48.53 \pm 0.89$ & $88.08 \pm 0.9$ & $36.8 \pm 2.4$ & $106.3 \pm 1.01$ & $95.9 \pm 7.5$ & $120.47 \pm 5.2$ & $56.49 \pm 0.61$ \\
\hline $\mathrm{Zn}(\mathrm{a})$ & $26.81 \pm 2.79$ & $1.72 \pm 0.21$ & $12.01 \pm 0.58$ & $1.70 \pm 0.18$ & $11.51 \pm 0.44$ & $1.53 \pm 0.16$ & $13.67 \pm 2.14$ & $36.35 \pm 2.52$ & $15.13 \pm 2.2$ & $2.36 \pm 0.34$ \\
\hline $\mathrm{Cu}(\mathrm{t})$ & $0.809 \pm 0.01$ & $2.35 \pm 0.32$ & $7.52 \pm 0.16$ & $5.17 \pm 0.01$ & $27.15 \pm 1.10$ & $2.52 \pm 0.27$ & $28.51 \pm 1.46$ & $3.55 \pm 0.14$ & $21.49 \pm 0.84$ & $9.39 \pm 0.14$ \\
\hline $\mathrm{Cu}(\mathrm{a})$ & $0.97 \pm 0.04$ & $0.516 \pm 0.04$ & $<\mathrm{UDL}$ & $<\mathrm{UDL}$ & $<\mathrm{UDL}$ & $<\mathrm{UDL}$ & $1.47 \pm 0.02$ & $<\mathrm{UDL}$ & $<\mathrm{UDL}$ & $3.33 \pm 0.04$ \\
\hline $\mathrm{Cr}(\mathrm{t})$ & $153.9 \pm 26$ & $1748.2 \pm 21$ & $837.4 \pm 15$ & $674.5 \pm 15$ & $539.3 \pm 11$ & $267.5 \pm 36$ & $798.7 \pm 11$ & $402.6 \pm 10$ & $305.7 \pm 1.09$ & $804.2 \pm 8.0$ \\
\hline $\mathrm{Cr}$ (a) & $0.53 \pm 0.2$ & $47.31 \pm 0.03$ & $<\mathrm{UDL}$ & $15.79 \pm 1$ & $5.14 \pm 0.33$ & $4.13 \pm 0.33$ & $17.44 \pm 0.16$ & $9.34 \pm 0.03$ & $<\mathrm{UDL}$ & $<\mathrm{UDL}$ \\
\hline $\mathrm{Co}(\mathrm{t})$ & $243.1 \pm 9.8$ & $201.4 \pm 6.4$ & $76.38 \pm 12$ & $211.8 \pm 12$ & $224.3 \pm 17$ & $229.2 \pm 15$ & $234.4 \pm 11$ & $296.8 \pm 18$ & $200.2 \pm 14.9$ & $204.8 \pm 14$ \\
\hline Co (a) & $9.31 \pm 2.2$ & $21.21 \pm 1.5$ & $20.56 \pm 1.9$ & $73.07 \pm 10.5$ & $65.37 \pm 4.3$ & $49.67 \pm 4.5$ & $55.19 \pm 6.9$ & $73.66 \pm 2.9$ & $51.48 \pm 3.9$ & $86.92 \pm 6.5$ \\
\hline $\mathrm{Cd}(\mathrm{t})$ & $1.34 \pm 0.14$ & $3.38 \pm 0.21$ & $3.83 \pm 0.05$ & $<\mathrm{UDL}$ & $3.58 \pm 0.06$ & $<\mathrm{UDL}$ & $1.88 \pm 0.008$ & $<\mathrm{UDL}$ & $2.29 \pm 0.26$ & $2.88 \pm 0.02$ \\
\hline $\mathrm{Cd}(\mathrm{ae})$ & $0.52 \pm 0.001$ & $1.47 \pm 0.12$ & $<\mathrm{UDL}$ & $<\mathrm{UDL}$ & $<\mathrm{UDL}$ & $<\mathrm{UDL}$ & $0.435 \pm 0.12$ & $<\mathrm{UDL}$ & $0.262 \pm 0.001$ & $1.34 \pm 0.02$ \\
\hline $\mathrm{Pb}(\mathrm{t})$ & $17.59 \pm 0.02$ & $46.93 \pm 0.97$ & $128.09 \pm 0.47$ & $86.97 \pm 0.42$ & $11.41 \pm 0.02$ & $13.68 \pm 0.05$ & $71.52 \pm 0.15$ & $32.06 \pm 0.44$ & $21.07 \pm 0.97$ & $128.7 \pm 0.02$ \\
\hline $\mathrm{Pb}(\mathrm{a})$ & $<\mathrm{UDL}$ & $<\mathrm{UDL}$ & $12.70 \pm 0.01$ & $0.679 \pm 0.05$ & $<\mathrm{UDL}$ & $<\mathrm{UDL}$ & $1.42 \pm 0.03$ & $<\mathrm{UDL}$ & $4.71 \pm 0.01$ & $37.21 \pm 0.20$ \\
\hline
\end{tabular}


Table 3. Concentrations of analysed elements in Alyssum murale roots, stems and leaves (mean $\pm S D$ )

\begin{tabular}{|c|c|c|c|c|c|c|c|c|c|c|}
\hline Sample point & SP1 & SP2 & SP3 & SP4 & SP5 & SP6 & SP7 & SP8 & SP9 & SP10 \\
\hline Fe root & $319.1 \pm 12$ & $885.2 \pm 8.6$ & $2328.7 \pm 251$ & $480.2 \pm 1.2$ & $435.8 \pm 25$ & $471.6 \pm 14$ & $122.2 \pm 1.9$ & $364.9 \pm 5.7$ & $461.3 \pm 5.7$ & $547.7 \pm 179$ \\
\hline Fe stem & $144.7 \pm 14$ & $1159.1 \pm 41$ & $1600.8 \pm 157$ & $386.7 \pm 4.9$ & $763.5 \pm 43$ & $279.3 \pm 4.1$ & $306.3 \pm 5.0$ & $685.2 \pm 7.0$ & $835.8 \pm 35$ & $637.1 \pm 21$ \\
\hline Fe leaves & $213.1 \pm 22$ & $1454.1 \pm 39$ & $1172.8 \pm 47$ & $755.9 \pm 3.7$ & $928.4 \pm 12$ & $637.3 \pm 39$ & $334.7 \pm 13$ & $964.7 \pm 35$ & $562.4 \pm 26$ & $444.5 \pm 17$ \\
\hline Ca root & $8273.3 \pm 64$ & $5323.5 \pm 3.7$ & $3243.5 \pm 40$ & $7343.9 \pm 26$ & $8385.5 \pm 42$ & $5138.6 \pm 99$ & $3819.5 \pm 23$ & $4417.3 \pm 31$ & $7757.1 \pm 26$ & $8653.1 \pm 20$ \\
\hline Ca stem & $41419.2 \pm 42$ & $29255.8 \pm 18$ & $19170.1 \pm 17$ & $22276.4 \pm 11$ & $11362.6 \pm 9.5$ & $33454.6 \pm 18$ & $9849.2 \pm 19$ & $7233.6 \pm 31$ & $17569.9 \pm 6.6$ & $19504.5 \pm 3.8$ \\
\hline Ca leaves & $61169.2 \pm 1.9$ & $42197.7 \pm 3.9$ & $41132.0 \pm 10$ & $55115.8 \pm 4.2$ & $17283.7 \pm 16$ & $53660.3 \pm 25$ & $22733.3 \pm 40$ & $13104.2 \pm 24$ & $42344.2 \pm 33$ & $33458.6 \pm 36$ \\
\hline $\mathrm{Mg}$ root & $2184.1 \pm 41$ & $5283.5 \pm 34$ & $2537.4 \pm 365$ & $2522.6 \pm 4.7$ & $2367.6 \pm 245$ & $1158.7 \pm 12$ & $2052.2 \pm 169$ & $5157.6 \pm 395$ & $956.9 \pm 7.2$ & $1669.3 \pm 232$ \\
\hline Mg stem & $2608.6 \pm 217$ & $5363.2 \pm 33$ & $3766.7 \pm 31$ & $3111.4 \pm 6.3$ & $3076.8 \pm 321$ & $2866.2 \pm 453$ & $2840.5 \pm 326$ & $8250.5 \pm 400$ & $1715.3 \pm 66$ & $2855.9 \pm 337$ \\
\hline Mg leaves & $9686.3 \pm 150$ & $8200.7 \pm 14$ & $9620.3 \pm 110$ & $5220.9 \pm 6.3$ & $5337.4 \pm 538$ & $6251.9 \pm 647$ & $6457.4 \pm 528$ & $10103.4 \pm 31$ & $2974.1 \pm 323$ & $4541.1 \pm 411$ \\
\hline $\mathrm{Ni}$ root & $1009.9 \pm 6.1$ & $1808.9 \pm 14$ & $1738.6 \pm 47$ & $983.9 \pm 3.1$ & $2386.7 \pm 52$ & $1123.8 \pm 48$ & $2504.7 \pm 356$ & $2076.2 \pm 178$ & $2647.7 \pm 67$ & $5885.4 \pm 11$ \\
\hline Ni stem & $3314.3 \pm 116$ & $2400.9 \pm 2.1$ & $2885.7 \pm 349$ & $1336.8 \pm 45$ & $2838.1 \pm 178$ & $2323.8 \pm 13$ & $2938.1 \pm 24$ & $4219.1 \pm 178$ & $3742.8 \pm 233$ & $7409.5 \pm 178$ \\
\hline Ni leaves & $9695.2 \pm 178$ & $7821.3 \pm 1.5$ & $4457.1 \pm 308$ & $2304.5 \pm 2.4$ & $6028.6 \pm 308$ & $7457.1 \pm 617$ & $6504.7 \pm 293$ & $8933.3 \pm 793$ & $5481 \pm 299$ & $10552.4 \pm 242$ \\
\hline Mn root & $38.16 \pm 3.3$ & $22.38 \pm 0.6$ & $30.76 \pm 2.4$ & $11.88 \pm 0.4$ & $24.29 \pm 1.3$ & $100.5 \pm 2.5$ & $14.88 \pm 2.8$ & $7.06 \pm 2$ & $18.92 \pm 0.8$ & $44.59 \pm 2.2$ \\
\hline Mn stem & $17.91 \pm 1.9$ & $33.19 \pm 1.6$ & $15.18 \pm 2.5$ & $63.51 \pm 1.2$ & $39.11 \pm 4.9$ & $99.03 \pm 0.7$ & $36.21 \pm 4.3$ & $16.73 \pm 3.3$ & $19.86 \pm 0.9$ & $66.99 \pm 1.9$ \\
\hline Mn leaves & $97.61 \pm 7.8$ & $43.52 \pm 0.4$ & $109.6 \pm 6.8$ & $71.85 \pm 0.4$ & $95.01 \pm 2.4$ & $135.0 \pm 0.5$ & $101.1 \pm 7.8$ & $36.25 \pm 2$ & $71.26 \pm 5.3$ & $107.5 \pm 5.9$ \\
\hline $\mathrm{Zn}$ root & $26.09 \pm 2.2$ & $8.28 \pm 0.0002$ & $2.62 \pm 0.1$ & $8.09 \pm 0.1$ & $2.46 \pm 0.1$ & $1.72 \pm 0.2$ & $5.64 \pm 0.3$ & $7.44 \pm 0.7$ & $7.26 \pm 0.2$ & $9.81 \pm 0.4$ \\
\hline Zn stem & $13.21 \pm 0.5$ & $9.86 \pm 0.7$ & $3.24 \pm 0.1$ & $2.14 \pm 0.7$ & $5.37 \pm 1.9$ & $4.45 \pm 0.2$ & $1.46 \pm 0.1$ & $1.69 \pm 0.3$ & $0.61 \pm 0.2$ & $2.64 \pm 0.04$ \\
\hline Zn leaves & $4.34 \pm 0.2$ & $11.28 \pm 0.01$ & $3.04 \pm 0.6$ & $2.62 \pm 0.4$ & $4.33 \pm 0.5$ & $0.51 \pm 0.1$ & $0.49 \pm 0.09$ & $0.35 \pm 0.09$ & $1.17 \pm 0.06$ & $1.25 \pm 0.3$ \\
\hline Co root & $30.61 \pm 8.3$ & $41.20 \pm 0.82$ & $11.96 \pm 1.32$ & $13.16 \pm 0.16$ & $23.94 \pm 12$ & $12.10 \pm 0.80$ & $115.5 \pm 5.0$ & $56.49 \pm 4.0$ & $54.28 \pm 4.9$ & $55.81 \pm 4.1$ \\
\hline Co stem & $73.05 \pm 8.6$ & $52.89 \pm 0.50$ & $19.63 \pm 0.72$ & $20.91 \pm 1.21$ & $11.89 \pm 1.31$ & $58.29 \pm 5.3$ & $19.51 \pm 0.6$ & $11.93 \pm 1.3$ & $12.03 \pm 1.4$ & $38.87 \pm 1.4$ \\
\hline Co leaves & $142.8 \pm 8.3$ & $81.36 \pm 0.64$ & $122.2 \pm 8.3$ & $38.05 \pm 0.08$ & $20.61 \pm 0.16$ & $39.84 \pm 0.76$ & $51.76 \pm 1.05$ & $115.6 \pm 17$ & $41.22 \pm 1.1$ & $19.29 \pm 0.8$ \\
\hline Cd root & $1.87 \pm 0.25$ & $1.25 \pm 0.04$ & $0.652 \pm 0.4$ & $2.72 \pm 0.06$ & $1.39 \pm 0.51$ & $1.03 \pm 0.53$ & $2.63 \pm 1.0$ & $0.896 \pm 0.27$ & $2.06 \pm 0.41$ & $1.41 \pm 0.37$ \\
\hline Cd stem & $1.76 \pm 0.9$ & $1.8 \pm 0.02$ & $2.41 \pm 0.18$ & $3.21 \pm 0.08$ & $2.81 \pm 0.17$ & $3.63 \pm 0.36$ & $2.20 \pm 0.21$ & $2.66 \pm 0.38$ & $1.709 \pm 0.64$ & $2.14 \pm 0.16$ \\
\hline Cd leaves & $3.47 \pm 0.6$ & $2.42 \pm 0.25$ & $2.22 \pm 0.23$ & $4.30 \pm 0.28$ & $2.38 \pm 0.58$ & $2.39 \pm 0.40$ & $2.00 \pm 0.49$ & $3.11 \pm 0.57$ & $0.582 \pm 0.45$ & $1.89 \pm 0.29$ \\
\hline $\mathrm{Pb}$ root & $8.23 \pm 0.4$ & $2.21 \pm 0.05$ & $6.87 \pm 0.4$ & $<\mathrm{UDL}$ & $2.48 \pm 0.2$ & $3.82 \pm 0.5$ & $13.02 \pm 0.6$ & $16.59 \pm 0.3$ & $27.26 \pm 0.4$ & $14.17 \pm 0.9$ \\
\hline $\mathrm{Pb}$ stem & $10.96 \pm 0.7$ & $1.34 \pm 0.04$ & $18.07 \pm 0.6$ & $<\mathrm{UDL}$ & $17.97 \pm 0.7$ & $8.00 \pm 0.1$ & $43.09 \pm 3.8$ & $26.78 \pm 0.8$ & $17.96 \pm 0.07$ & $5.60 \pm 0.4$ \\
\hline $\mathrm{Pb}$ leaves & $17.30 \pm 0.4$ & $3.45 \pm 0.3$ & $16.59 \pm 0.9$ & $<\mathrm{UDL}$ & $8.57 \pm 0.4$ & $6.24 \pm 0.4$ & $27.16 \pm 0.4$ & $16.48 \pm 1$ & $17.83 \pm 0.7$ & $9.50 \pm 0.3$ \\
\hline
\end{tabular}

Abbreviation used: <UDL - under the detection limit 


\section{Relationship between metal concentrations in soil and plants}

The results of principal components analysis of the measured element concentrations in investigated soil samples are presented in Table 4 and Figure 2. PCA rendered five principal components with eigenvalues greater than 1.00 , accounting for $86.8 \%$ of the total variability of analysed data set. Taking into account these five factors, percentage of variable communalities ranged from $65.9 \%$ for $\mathrm{Cu}$, up to $95.2 \%$ for $\mathrm{K}$, so that they provide a good overview of all analyzed elements. The first component (PC1) explaining $30.0 \%$ of the total variance, showed a strong negative correlation with $\mathrm{Ni}$, $\mathrm{Co}$ and $\mathrm{Mg}$, and a moderate positive one with $\mathrm{Cr}$ and $\mathrm{Cd}$. Namely, PC1 that was mostly determined by elements originating forom parent rock, separated sites characterized by the highest concentrations of $\mathrm{Ni}, \mathrm{Co}$ and $\mathrm{Mg}$, with somewhat lower concentrations of $\mathrm{Cr}$ and $\mathrm{Cd}$. The second component (PC2), which explained $18.8 \%$ of the total variance, showed strong positive correlation with $\mathrm{P}$ and strong negetive one with $\mathrm{Zn}$. Finally, the third, fourth and fifth principal components, explaining 15,9\%,11.8\% and 10,2\% of the total variance, were mostly determined by $\mathrm{Ca}, \mathrm{Fe}$ and $\mathrm{Mn}$ concentrations, respectively.

Results of correlation analyses of metal concentrations in A. murale showed the strongest synergism for $\mathrm{K}-\mathrm{Pb}$ in boath roots and shoots, and the strongest antagonism for $\mathrm{Fe}-\mathrm{Zn}$ in roots, and $\mathrm{Ca}-\mathrm{K}$ in shoots (Table 5). Regardin the concentrations of metals in plant tissues (roots, stems and leaves) in relation to their available concentrations in soil samples, the strongest positive correlation was noticed between $\mathrm{Ca}$ concentration in soil and those in both leaves and stems, while the strongest negativ one between $\mathrm{Zn}$ in soil and those in rootsand stems (Table 6).

More detailed relations between available trace metals in soil and plant tissues can be observed from the calculated values of bioconcentration and and translocation factor (Table 7). The obtained values of bioconcentration factors indicated a good uptake efficiency for all elements listed, except Mn for wich the BCF was less than 1 in all investigatet localities. In respect of translocation factor, efficient translocation is also observed, except for $\mathrm{Zn}$ which was mostly stored in root.

Table 4. Factor loadings, percentage of variable communalities, eigenvalue and percentages of variance for the first five principal components (PC1-PC5, factor loadings > 0.75 are indicated in bold)

\begin{tabular}{lcccccc}
\hline Parameter & PC1 & PC2 & PC3 & PC4 & PC5 & $\begin{array}{c}\text { \% of } \\
\text { comunlity }\end{array}$ \\
\hline $\mathrm{Ca}$ & -0.2086 & 0.1846 & 0.7452 & -0.1565 & 0.5311 & 94.0 \\
$\mathrm{Mg}$ & $\mathbf{- 0 . 7 5 2 8}$ & -0.1875 & 0.2838 & -0.1821 & 0.2931 & 80.1 \\
$\mathrm{P}$ & 0.1611 & $\mathbf{0 . 8 7 3 5}$ & 0.0257 & 0.0552 & 0.0576 & 79.6 \\
$\mathrm{~K}$ & 0.5334 & -0.2465 & 0.6526 & -0.4145 & 0.0941 & 95.2 \\
$\mathrm{Fe}$ & 0.0567 & 0.4404 & 0.6049 & 0.6220 & 0.0011 & 95.0 \\
$\mathrm{Ni}$ & $\mathbf{- 0 . 8 8 8 6}$ & 0.1626 & -0.095 & -0.1218 & 0.3285 & 94.8 \\
$\mathrm{Zn}$ & 0.1619 & $\mathbf{- 0 . 8 6 9 7}$ & 0.1610 & 0.1549 & -0.1451 & 85.4 \\
$\mathrm{Mn}$ & -0.2517 & -0.2351 & -0.4363 & 0.3687 & 0.6212 & 83.1 \\
$\mathrm{Cu}$ & 0.3906 & -0.5875 & -0.1119 & 0.1268 & 0.3641 & 65.9 \\
$\mathrm{Cr}$ & 0.6547 & 0.4068 & -0.5171 & -0.0721 & 0.225 & 91.7 \\
$\mathrm{~Pb}$ & 0.5577 & 0.0880 & -0.2478 & -0.5973 & 0.3717 & 87.5 \\
$\mathrm{Cd}$ & 0.6818 & -0.0455 & 0.0798 & 0.5932 & 0.3365 & 93.8 \\
$\mathrm{Co}$ & $\mathbf{- . 8 6 0 9}$ & -0.0399 & -0.2653 & 0.1243 & -0.0202 & 82.9 \\
\hline Eigenvalue & 3.9 & 2.4 & 2.1 & 1.5 & 1.3 & \\
\% Total & 30.0 & 18.8 & 15.9 & 11.8 & 10.2 & \\
variance & & & & & & \\
\hline
\end{tabular}




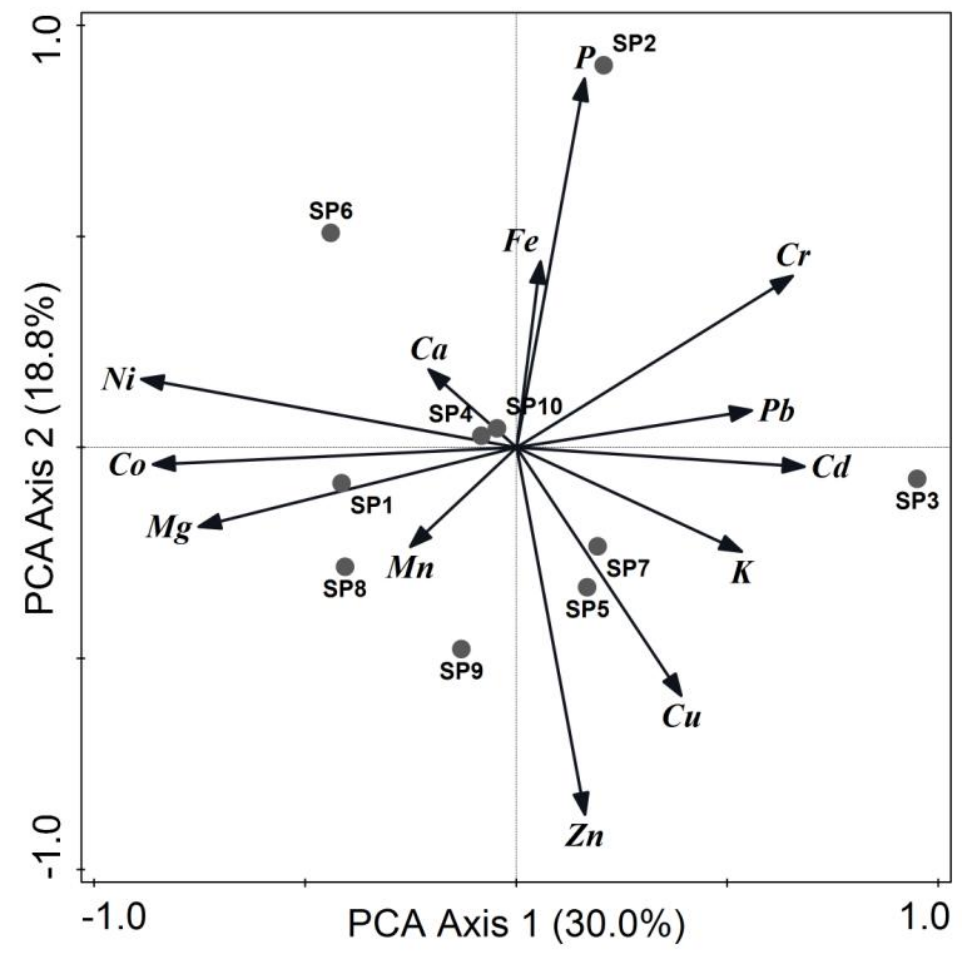

Figure 2. PCA biplot combining data on soil element concentrations from ten serpentine locations in Bosnia and Herzegovina. The first two axes account for $48.8 \%$ of the total variance are shown

Table 5. Correlation between elements concentrations in roots and shoots of Alyssum murale (the upper right part refers to the shoots and the lower left to the roots). Significant correlation coefficients are in bold $(* p<0.05 ; * * p<0.01$ and $* * * p<0.001)$

\begin{tabular}{ccccccccccc}
\hline & $\mathbf{C a}$ & $\mathbf{C d}$ & $\mathbf{C o}$ & $\mathbf{F e}$ & $\mathbf{K}$ & $\mathbf{M g}$ & $\mathbf{M n}$ & $\mathbf{N i}$ & $\mathbf{P b}$ & $\mathbf{Z n}$ \\
\hline $\mathbf{C a}$ & & 0.04 & $\mathbf{0 . 3 6}$ & -0.27 & $\mathbf{- 0 . 6 2} * * *$ & -0.21 & $\mathbf{0 . 4 2} *$ & -0.21 & $\mathbf{- 0 . 4 8} * *$ & $\mathbf{0 . 7 1} * * *$ \\
$\mathbf{C d}$ & 0.36 & & 0.19 & -0.13 & -0.32 & $\mathbf{0 . 4 7} * *$ & 0.16 & -0.32 & $\mathbf{- 0 . 4 3}$ & -0.33 \\
$\mathbf{C o}$ & -0.02 & 0.27 & & -0.15 & -0.05 & $\mathbf{0 . 7 0} * * *$ & -0.29 & 0.24 & 0.11 & 0.09 \\
$\mathbf{F e}$ & -0.20 & $\mathbf{- 0 . 4 8}$ & $\mathbf{- 0 . 5 7 * * *}$ & & -0.16 & 0.17 & -0.36 & -0.21 & -0.15 & 0.25 \\
$\mathbf{K}$ & -0.10 & -0.07 & $\mathbf{0 . 5 8} * * *$ & $\mathbf{- 0 . 5 0 * *}$ & & 0.01 & -0.23 & $\mathbf{0 . 5 7} * *$ & $\mathbf{0 . 7 2} * * *$ & $\mathbf{- 0 . 5 8 * * *}$ \\
$\mathbf{M g}$ & -0.32 & -0.18 & 0.10 & 0.15 & -0.12 & & $\mathbf{- 0 . 4 4} *$ & 0.14 & 0.08 & -0.32 \\
$\mathbf{M n}$ & 0.16 & -0.25 & $\mathbf{- 0 . 4 0 *}$ & 0.24 & -0.20 & $\mathbf{- 0 . 5 5} * *$ & & -0.11 & -0.15 & 0.27 \\
$\mathbf{N i}$ & 0.14 & -0.08 & $\mathbf{0 . 5 8} * * *$ & -0.06 & $\mathbf{0 . 5 3 * *}$ & -0.12 & -0.07 & & $\mathbf{0 . 5 9} * * *$ & -0.25 \\
$\mathbf{P b}$ & -0.13 & -0.12 & $\mathbf{0 . 6 4} * * *$ & -0.23 & $\mathbf{0 . 6 4} * * *$ & -0.28 & -0.05 & $\mathbf{0 . 5 6} * *$ & & $\mathbf{- 0 . 3 9 *}$ \\
$\mathbf{Z n}$ & -0.16 & -0.12 & $\mathbf{- 0 . 4 6 *}$ & $\mathbf{0 . 5 9} * * *$ & $\mathbf{- 0 . 5 7 * *}$ & -0.07 & $\mathbf{0 . 5 2} * *$ & -0.13 & $\mathbf{- 0 . 4 8 * *}$ & \\
\hline
\end{tabular}

Table 6. Correlation between available elements concentrations in in soil and plants tissues (root, stem and leaves) of Alyssum murale. Significant correlation coefficients are in bold ${ }^{*} p$ $<0.05 ; * * p<0.01$ and $* * * p<0.001$ )

\begin{tabular}{ccccccccccc}
\hline & Ca & Cd & Co & Fe & K & Mg & Mn & Ni & Pb & Zn \\
\hline roots & 0.23 & 0.13 & 0.18 & 0.16 & -0.06 & $\mathbf{- 0 . 3 8}^{*}$ & $\mathbf{0 . 5 8}^{* * *}$ & 0.04 & $\mathbf{0 . 4 1}^{*}$ & $\mathbf{- 0 . 7 7}^{* * *}$ \\
steams & $\mathbf{0 . 6 3}^{* * *}$ & $\mathbf{- 0 . 4 8}^{* *}$ & $\mathbf{- 0 . 5 4}^{* * *}$ & -0.07 & 0.00 & -0.17 & 0.28 & 0.14 & 0.08 & $\mathbf{- 0 . 6 6}^{* * *}$ \\
leaves & $\mathbf{0 . 6 4}^{* * *}$ & -0.14 & $\mathbf{- 0 . 7 2}^{* * *}$ & -0.09 & 0.22 & -0.18 & $\mathbf{0 . 6 0}^{* * * *}$ & 0.29 & 0.22 & -0.15 \\
\hline
\end{tabular}


Table 7. Bioconcentration factor (BCF) and translocation factor $(T F)$ of Alyssum murale

\begin{tabular}{|c|c|c|c|c|c|c|}
\hline & $\mathbf{N i}$ & $\mathbf{Z n}$ & Mn & $\mathbf{P b}$ & Cd & Co \\
\hline \multicolumn{7}{|c|}{ BCF (shoot/soil) } \\
\hline SP1 & 6.48 & 0.65 & 0.20 & - & 10.06 & 23.19 \\
\hline SP2 & 9.03 & 68.39 & 0.14 & - & 2.86 & 6.33 \\
\hline SP3 & 22.57 & 4.46 & 0.25 & 2.73 & - & 6.90 \\
\hline SP4 & 1.93 & 20.44 & 0.32 & 0.00 & - & 0.81 \\
\hline SP5 & 5.43 & 0.84 & 0.21 & - & - & 0.50 \\
\hline SP6 & 6.72 & 28.08 & 0.49 & - & - & 1.98 \\
\hline SP7 & 7.28 & 1.48 & 0.29 & 49.41 & 9.67 & 1.29 \\
\hline SP8 & 7.02 & 0.08 & 0.35 & - & - & 1.73 \\
\hline SP9 & 7.96 & 3.73 & 0.13 & 7.60 & 8.75 & 1.03 \\
\hline SP10 & 8.82 & 12.78 & 0.20 & 0.41 & 3.01 & 0.67 \\
\hline \multicolumn{7}{|c|}{ TF (shoot/root) } \\
\hline SP1 & 12.88 & 0.57 & 3.03 & 3.43 & 2.81 & 7.05 \\
\hline SP2 & 5.65 & 0.57 & 3.43 & 2.17 & 3.38 & 3.26 \\
\hline SP3 & 4.22 & 0.23 & 4.06 & 5.05 & 7.11 & 11.86 \\
\hline SP4 & 3.70 & 0.29 & 11.39 & - & 2.75 & 4.48 \\
\hline SP5 & 3.71 & 0.45 & 5.52 & 10.66 & 3.72 & 1.36 \\
\hline SP6 & 8.70 & 0.32 & 2.33 & 3.73 & 5.81 & 8.11 \\
\hline SP7 & 3.77 & 0.59 & 9.22 & 5.39 & 1.60 & 0.62 \\
\hline SP8 & 6.33 & 0.41 & 7.51 & 2.61 & 6.45 & 2.26 \\
\hline SP9 & 3.48 & 2.39 & 4.81 & 1.31 & 1.11 & 0.98 \\
\hline SP10 & 3.05 & 0.25 & 3.91 & 1.07 & 2.86 & 1.04 \\
\hline
\end{tabular}

\section{Discussion}

According to our results ten serpentine soil samples from central Bosnia and Herzegovina have typical ultramafic composition, with the moderate-to-high concentration of available $\mathrm{Mg}$, low-to-moderate available $\mathrm{Ca}$ content and elevated total concentrations of trace elements such as $\mathrm{Ni}, \mathrm{Mn}, \mathrm{Co}$, and $\mathrm{Cr}$. Moreover, the association of elements originatig from ultramafic bedrock which occur in high concentrations in these soils is also confirmed by the results of pricipal component analysis. Regarding treshold values of trace metals which are typical for ultramafic soils Kabata-Pendias et al. (2011) indicated that total Ni concentration of these soils are normally in the range $1400-2000 \mathrm{mg} / \mathrm{kg}$, Co content is from 35 to $200 \mathrm{mg} / \mathrm{kg}$, Cr from 170 to $3400 \mathrm{mg} / \mathrm{kg}$, while total Mn content of serpentine soils differ from 411 to $550 \mathrm{mg} / \mathrm{kg}$.

Results of our study showed the Ni content in the analysed soils of central Bosnia and Herzegovina are very high and within the range of the previously detected values for ultramafic soil samples from other Balkan Peninsula locations, Turkie, and Iran. The Co concetrations at our locations are slightly higher (Shallari et al., 1998; Ghaderian et al., 2007; Reeves and Adigüzel, 2008; Bani et al., 2010; Kazakou et al., 2010; Tumi et al. 2012; Tomović et al., 2013). Taking into account that all the sampling locations are situated far from the housholds, mainly close to the roads, thus it will be very easy to harvest plants which grow there, and they are excellent candidate sites for $\mathrm{Ni}$ phytomining (Tappero et al., 2007; Bani et al, 2015; Van der Ent et al., 2015; Nkrumah et al., 2016). On the other side, total Mn concentration in some other serpentine soils of Serbia was significantly higher, while total $\mathrm{Cr}$ value was much higher than on other Balkan peninsula serpentinite locations (Obratov-Petrović et al., 2008; Reeves et al., 2008; Bani et al., 2010) than investigated in our study. 
Concerning the trace metal accumulation potential of $A$. murale from Bosnia and Herzegovina, the very high efficiency of Ni uptake is presented. Namely, the content of $\mathrm{Ni}$ in analysed tissue samples from Bosnia was variable, where the highest concentration was detected in leaves, and the lowest in the roots. Similar situation was confirmed in Serbian population of $A$. murale where significant interpopulation inconsistency in $\mathrm{Ni}$ concentrations among analyzed populations in all plant tissues is shown (Tumi et al., 2012). Generally, in all the plant samples studied concentration of $\mathrm{Ni}$ was higher in the shoots compared to the roots. This could be endorsed to easy translocation of $\mathrm{Ni}$ throught the A. murale tissues, which is confirmed by the high values of translocation factor. According to Broadhurst and Chaney (2016), Ni is accumulated mainly in the leaves, especially in vacuoles of epidermal cells and trichome pedicels of $A$. murale population from Kotodesh in Albania. Although, Ni contents in Bosnian A. murale leaves (up to $10552.4 \mathrm{mg} / \mathrm{kg}$ ) are lower than those recorded by Bani et al. (2010) in populations of A. murale from Albania (up to 20100 $\mathrm{mg} / \mathrm{kg}$ ), this value is still in the range of those characteristic of Ni hyperaccumulators (Van der Ent et al., 2013). Therefore, the Bosnian population of A. murale is one of the best possible candidates for Ni phytomining at the local scale.

The high values of biococentration factor in Bosnian population of A. murale were also detected for Co. As in the case of $\mathrm{Ni}$, the obtained values of translocation factor for Co were also high, thus the highest concentration of this element was detected in leaves. Althoug the Co content in leaves of Bosnian population of A. murale (up to 142.9 $\mathrm{mg} / \mathrm{kg}$ ) were under a treshold value for Co hyperaccumulators $(1000 \mathrm{mg} / \mathrm{kg})$, it was significantly higher than those recorded in populations of $A$. murale from other Balkan countries (Bani et al., 2010; Tumi et al., 2012). This may be explained by the slightly higher Co concentrations of Bosnian soils, given that Tappero et al. (2007) have shown that $A$. murale could accumulate high concentrations of Co in experimental conditions in which nutrient solutions were Co enriched. However, unlike Ni which acumulates mainly in epidermal cells, Co is stored at the leaf tips/margins (Tappero et al. 2007).

Results obtained in this study show that Mn content in soil samples was significantly higher than in plant tissues samples, thus having a low bioconcentration factor, as in the case of A. murale from other Balkan countries (Bani et al., 2010; Tumi et al., 2012). The lowest Mn concentration was detected in A. murale roots, while the highest $\mathrm{Mn}$ content was confirmed in leaves. Zn content has similar trend in plant tissue and soils samples as Mn content. The low Zn content in plant tissue samples, especially in leaves, compared to the $\mathrm{Zn}$ content which was significantly higher in soil samples. Tappero et al. (2007) recorded the same trend for $\mathrm{Zn}$ in experimental conditions, i.e. moderate values of bioconcentration factor and low values of translocation factor. Moreover, $A$. murale does not accumulate $\mathrm{Zn}$, even when the nutrient sulution is enriched with this element (Tappero et al. 2007).

\section{Conclusion}

In this study ten soil samples collected from the central Bosnia and Herzegovina showed high level of $\mathrm{Ni}, \mathrm{Mn}, \mathrm{Co}$ and $\mathrm{Cr}$ microelements. The relationship between $\mathrm{Mg}$ and $\mathrm{Ca}$ in all ten soil samples was relatively high as expected and proven in previous studies. Ca concentration, as one of the most important macroelements, was relatively low in soil samples, while in all investigated plant tissue samples of A. murale Ca content was significantly higher which also corelates with previous studies. In all 
investigated tissue samples the $\mathrm{Ca}$ content was higher than $\mathrm{Mg}$ content as expected from serpentine soil weathered from serpentinite rock. The concentration of $\mathrm{Ni}$ in tissues of all investigated plant samples was high to extremely high while in one case it was 10 times higher in shoot than those in corresponding soil samples derived mainly of ultramafic origin.

According to previous study, metal hyperaccumulators are defined as plants that have the ability to accumulate Ni to such a level that dry leaf concentrations exceeds $1000 \mathrm{mg} / \mathrm{kg}(0.1 \%)$, so all A. murale plant samples from Bosnia and Herzegovina appear as strong Ni hyperaccumulators. Bearing in mind that all A. murale plant tissue investigated in our study share the same high capacity for accumulation of $\mathrm{Ni}$ and generally shared high tolerance to other metals, these plants could be very good candidates for application in phytoextraction process for phytoremediation and, especially, Ni phytomining.

Acknowledgements. This work was supported by the Ministry of Education, Science and Technological Development of the Republic of Serbia (Grant No. 173030).

\section{REFERENCES}

[1] Alexander, E.B, Coleman, R.G., Keeler-Wolfe, T. (2007): Serpentine Geoecology of Western North America: Geology, Soils, and Vegetation. - Oxford University Press: Cary, NC.

[2] Babalonas, D., Karataglis, S., Kabassakalis, V. (1984): The Ecology of Plant Populations Growing on Serpentine Soils. - Phyton 24: 225-238.

[3] Ball, P. W., Dudley, T. R (1993): Alyssum L.- Flora Europea 1:359-369m University Press, Cambridge.

[4] Bani, A., Echevarria, G., Sulçe, S., Mullaj, A., Morel, J.L. (2007): In-situ phytoextraction of nickel by native population of A. murale on ultramafic site in Albania. - Plant and Soil 293: 79-89.

[5] Bani, A., Echevarria, G., Mullaj, A., Reeves, R.D., Morel, J.L., Sulçe, S. (2009): Ni hyperaccumulation by Brassicaceae inserpentine soils of Albania and NW Greece. Northeastern Naturalist 16: 385-404.

[6] Bani, A., Pavlova, D., Echevarria, G., Mullaj, A. (2010): Nickel hyperaccumulation by the species of Alyssum and Thlaspi (Brassicaceae) from the ultramafic soils of the Balkans. - Botanica Serbica 4: 3-14.

[7] Bani, A., Imeri, A., Echevarria, G., Pavlova, D., Reeves, R.D., Morel, J.L., Sulç S. (2013): Nickel hyperaccumulation in the serpentine flora of Albania. - Fresenius Environmental Bulletin 22: 1792-1801.

[8] Bani, A., Echevarria, G., Sulçe, S. and Morel, J.L, (2015): Improving the agronomy of Alyssum murale for extensive phytomining: a five-year field study. - International Journal of Phytoremediation, 17: 117-127.

[9] Broadhurst, C.L., Chaney, R.L. (2016): Growth and Metal Accumulation of an Alyssum murale Nickel Hyperaccumulator Ecotype Co-cropped with Alyssum montanum and Perennial Ryegrass in Serpentine Soil. - Frontiers in plant science, 7: 451.

[10] Egner, H., Riehm, H., Domingo, W.R. (1960): Studies on the chemical soil analysis as a basis for the assessment of the ground nutrient status of the soil II Chemical Extraction methods to Phosphorus and Potassium determination. K. - Lantbr Hogsk Annlr WR 26: 199 [In German].

[11] FAO (1974): The Euphrates Pilot Irrigation Project. Methods of soil analysis, Gadeb Soil Laboratory (A laboratory manual). Food and AgricultureOrganization, Rome, Italy 
[12] Garcia, W.J., Blessin, C.W., Sandford, H.W., Inglett, G.E. (1979): Translation and accumulation of seven heavy metals in tissues of corn plants grown on sludge-treated stripmined soil. - Journal of agricultural and food chemistry 27:1088-1094.

[13] Ghaderian, S.M., Mohtadi, A., Rahiminejad, M.R., Baker, A.J.M. (2007): Nickel and other metal uptake and accumulation by species of Alyssum (Brassicaceae) from the ultramafics of Iran. - Environmental Pollution 145: 293-298.

[14] Ghosh, M., Singh, S.P. (2005): Comparative uptake and phytoextraction study of soil induced chromium by accumulator and high biomass weed species. - Applied Ecology and Environmental Research, 3: 67-79.

[15] Hartvig, P., (2002): Alyssum L. - In: Strid, A, Tan, K. (Eds.). Flora Hellenica 2.. Koeltz Scientific Books, pp 199-224.

[16] Jackson, M.L. (2005): Soil Chemical Analysis: Advanced Course. Parallel Press, Universityof Wisconsin- Madison Libraries.

[17] Kabata-Pendias, A. (2011): Trace Elements in Soils and Plants. - CRC Press, Florida, USA.

[18] Karataglis, S., Babalonas, D., Kabasakalis, B. (1982): The ecology of plant populations growing on serpentine soils ii. $\mathrm{Ca} / \mathrm{Mg}$ ratio and the $\mathrm{cr}, \mathrm{Fe}, \mathrm{Ni}$, Co concentrations as development factors of Buxus sempervirens 1. - Phyton (Austria) 22: 317-327.

[19] Kaiser, H.F., Rice, J. (1974): Little jiffy, mark IV. - Educational and psychological measurement, 34: 111-117.

[20] Kazakou, E., Adamidis, G.C., Baker, A.J.M., Reeves, R.D., Godino, M., Dimitrakopoulos, P.G. (2010): Species adaptation in serpentine soils in Lesbos Island (Greece): metal hyperaccumulation and tolerance. - Plant and Soil 332: 369-385.

[21] Lazarus, B.E., Richards, J.H., Claassen, V.P., O’Dell, R.E., Ferrell, M.A.. (2011): Species specific plant-soil interactions influence plant distribution on serpentine soils. - Plant and Soil 342: 327-344.

[22] Li, Y.M., Chaney, R.L., Brewer, E.P., Angle, J.S., Nelkin, J. (2003):. Phytoextraction of nickel and cobalt by hyperaccumulator Alyssum species grown on nickel-contaminated soils. - Environmental science \& technology, 37:1463-1468.

[23] Markert, B. (1995): Sample preparation (cleaning, drying, homogenization) for trace element analysis in plant matrices. - Science of the total environment, 176: 45-61.

[24] McKeague, J.A. (1978): Manual on soil sampling and methods of analysis. - Canadian Society of Soil Science, pp. 66-68.

[25] Obratov-Petković, D., Bjedov, I., Belanović, S. (2008): The content of heavy metals in the leaves of Hypericum perforatum L. on serpentinite soils in Serbia. - Glasnik Šumarskog fakulteta 98: 143-153.

[26] Nkrumah, P.N., Baker, A.J., Chaney, R.L., Erskine, P.D., Echevarria, G., Morel, J.L. van der Ent, A., (2016): Current status and challenges in developing nickel phytomining: an agronomic perspective. - Plant and Soil, 406: 55-69.

[27] Oze, C., Fendorf, S., Bird, D.K., Coleman, R.G. (2004): Chromiun geochemistry in serpentinized ultramafi $\mathrm{c}$ rocks and serpentine soils from the Franciscan complex of California. - American Journal of Science, 304: 67-101.

[28] Pollard, A. J., Reeves, R. D., Baker, A. J. (2014): Facultative hyperaccumulation of heavy metals and metaloids. - Plant Science, 217: 8-17.

[29] Reeves, R.D., Kruckeberg, A.R., Adigüzel, N., Krämer, U. (2001): Studies on the flora of serpentine and other metalliferous areas of western Turkey. - South African Journal of Science 97: 513-517.

[30] Reeves, R.D., Adigüzel, N. (2008): The Nickel Hyperaccumulating Plants of the Serpentines of Turkey and Adjacent Areas: A Review with New Data. - Turkish Journal of Botany 32: 143-153.

[31] Reeves, R.D., Adiguzel, N., Baker, A.J.M. (2009): Nickel Hyperaccumulation in Bornmuellera kiyakii Aytac \& Aksoy and Associated Plants of the Brassicaceae from Kızıldağ (Derebucak, Konya-Turkey). - Turkish Journal of Botany 33: 33-40. 
[32] Rowell, D.L. (1997): Soil Science. Research methods and their applications. - Springer: Berlin. [In German].

[33] Shallari, S., Schwartza, C., Haskob, A., Morela, J.L. (1998): Heavy metals in soils and plants of serpentine and industrial sites of Albania. - Science of the total environment 209: 133-142.

[34] Stevanović, V., Tan, K., Iatrou, G. (2003): Distribution of the endemic Balkan flora on serpentine I. - obligate serpentine endemics. - Plant Systematics and Evolution 242: 149170 .

[35] Tappero, R., Peltier, E., Gräfe, M., Heidel, K., Ginder-Vogel, M., Livi, K.J.T., Rivers, M.L., Marcus, M.A., Chaney, R.L., Sparks, D.L. (2007): Hyperaccumulator Alyssum murale relies on a different metal storage mechanism for cobalt than for nickel. - New Phytologist, 175:.641-654.

[36] Tatić, V, Veljović, B. (1999): Distribution of serpentinized massives on the Balkan Peninsula and their ecology. BA Roberts and J Proctor (eds.). The ecology of area with serpentinized rocks. - A world wiew 199-215.

[37] Tomović, G.M., Mihailović, N.L., Tumi, A.F., Gajić, B.A., Mišljenović, T.D. Niketić, M.S. (2013): Trace metals in soils and several Brassicaceae plant species from serpentine sites of Serbia. Archives of Environmental Protection, 39(4): .29-49.

[38] Tumi, A.F., Mihailović, N., Gajić, B.A., Niketić, M., Tomović, G. (2012): Comparative Study of Hyperaccumulation of Nickel by Alyssum murale s.l. Populations from the Ultramafics of Serbia. - Pol J Environ Stud 21: 1855-1866.

[39] Van der Ent, A., Baker, A.J., Reeves, R.D., Pollard A.J., Schat, H., (2013): Hyperaccumulators of metal and metalloids trace elements: facts and fiction. - Plant and Soil, 362: 319-334.

[40] Van der Ent, A., Baker, A.J., Reeves, R.D., Chaney, R.L., Anderson, C.W., Meech, J.A., Erskine, P.D., Simonnot, M.O., Vaughan, J., Morel, J.L.. Echevarria, G., (2015): Agromining: farming for metals in the future? - Environmental Sciience and Technology, 49: 4773-4780

[41] Van Reeuwijk, L.P. (1995): Procedures for Soil Analysis. 5th ed. Technical Paper//International Soil Reference and Information Centre: - Wageningen.

[42] Van Reeuwijk, L.P. (2002): Procedures for Soil Analysis. 6th ed. Technical Paper/International Soil Reference and Information Centre: - Wageningen.

[43] Whiting, S.N., Neumann, M., Baker, A.J.M. (2003): Nickel and zinc hyperaccumulation by Alyssum murale and Thlaspi caerulescens (Brassicaceae) do not enhance survival and whole-plant growth under drought stress. - Plant, Cell and Environment 26: 351-360.

[44] Whittaker, R.H. (1954): The Ecology of Serpentine Soils. - Ecology 35: 258-288. 